\title{
Estimating Long-Term Mean Winds From Short-Term Wind Data
}

W. R. Barchet

W. E. Davis

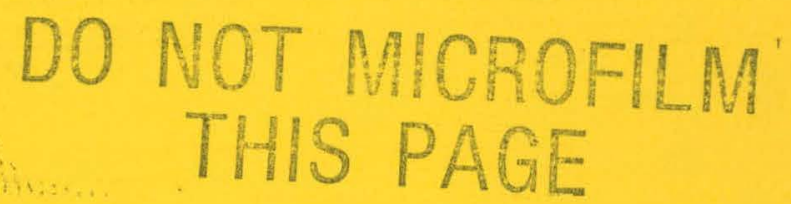

August 1983

Prepared for the U.S. Department of Energy under Contract DE-AC06-76RLO 1830

Pacific Northwest Laboratory

Operated for the U.S. Department of Energy

by Battelle Memorial Institute

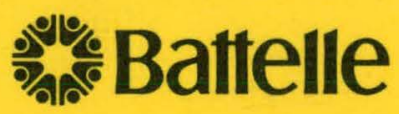




\section{DISCLAIMER}

This report was prepared as an account of work sponsored by an agency of the United States Government. Neither the United States Government nor any agency Thereof, nor any of their employees, makes any warranty, express or implied, or assumes any legal liability or responsibility for the accuracy, completeness, or usefulness of any information, apparatus, product, or process disclosed, or represents that its use would not infringe privately owned rights. Reference herein to any specific commercial product, process, or service by trade name, trademark, manufacturer, or otherwise does not necessarily constitute or imply its endorsement, recommendation, or favoring by the United States Government or any agency thereof. The views and opinions of authors expressed herein do not necessarily state or reflect those of the United States Government or any agency thereof. 


\section{DISCLAIMER}

Portions of this document may be illegible in electronic image products. Images are produced from the best available original document. 


\section{The following pages are an exact representation of what is in the original document folder.}




\title{
DO NOT MICROFILM THIS PAGE \\ Sitis.
}

\section{DISCLAIMER}

This report was prepared as an account of work sponsored by an agency of the United States Government. Neither the United States Government nor any agency thereof, nor any of their employees, makes any warranty, express or implied, or assumes any legal liability or responsibility for the accuracy, completeness, or usefulness of any information, apparatus, product, or process disclosed, or represents that its use would not infringe privately owned rights. Reference herein to any specific commercial product, process, or service by trade name, trademark, manufacturer, or otherwise, does not necessarily constitute or imply its endorsement, recommendation, or favoring by the United States Government or any agency thereof. The views and opinions of authors expressed herein do not necessarily state or reflect those of the United States Government or any agency thereof.

\author{
PACIFIC NORTHWEST LABORATORY \\ operated by \\ BATTELLE \\ for the \\ UNITED STATES DEPARTMENT OF ENERGY \\ under Contract DE-AC06-76RLO 1830
}

\begin{tabular}{|c|c|}
\hline \multicolumn{2}{|c|}{ Printed in the United States of America } \\
\hline \multicolumn{2}{|c|}{ le from } \\
\hline \multirow{2}{*}{\multicolumn{2}{|c|}{$\begin{array}{l}\text { National Technical Information Service } \\
\text { United States Department of Commerce }\end{array}$}} \\
\hline & \\
\hline \multicolumn{2}{|c|}{5285 Port Royal Road } \\
\hline \multicolumn{2}{|c|}{ Springfield, Virginia 22161} \\
\hline \\
\hline \multicolumn{2}{|c|}{ Microfiche A01 } \\
\hline \multicolumn{2}{|c|}{ Printed Copy } \\
\hline & Price \\
\hline Pages & Codes \\
\hline $001-025$ & $\mathrm{~A} \cap 2$ \\
\hline $026-050$ & $\mathrm{~A} 03$ \\
\hline 051-075 & $\mathrm{A} 04$ \\
\hline $076-100$ & A05 \\
\hline $101-125$ & A06 \\
\hline $126-150$ & $\mathrm{~A} 07$ \\
\hline $151-175$ & $\mathrm{~A} 08$ \\
\hline $176-200$ & A09 \\
\hline $201-225$ & A010 \\
\hline $226-250$ & $\mathrm{~A} 011$ \\
\hline $251-275$ & A012 \\
\hline $276-300$ & A013 \\
\hline
\end{tabular}




\section{DISCLAIMER}

This report was prepared as an account of work sponsored by an agency of the United States Government. Neither the United States Government nor any agency thereof, nor any of their employees, makes any warranty, express or implied, or assumes any legal liability or responsibility for the accuracy, completeness, or usefulness of any information, apparatus, product, or process disclosed, or represents that its use would not infringe privately owned rights. Reference herein to any specific commercial product, process, or service by trade name, trademark, manufacturer, or otherwise does not necessarily constitute or imply its endorsement, recommendation, or favoring by the United States Government or any agency thereof. The views and opinions of authors expressed herein do not necessarily state or reflect those of the United States Government or any agency thcreof. ESTIMATING LONG-TERM MEAN WINDS
FROM SHORT-TERM WIND DATA
PNL -4785

DE83 017417

W. R. Barchet

W. E. Davis

August 1983

Prepared for the

U.S. Department of Energy

under Contract DE-AC06-76RLO 1830

Pacific Northwest Laboratory

Richland, Washington 99352 


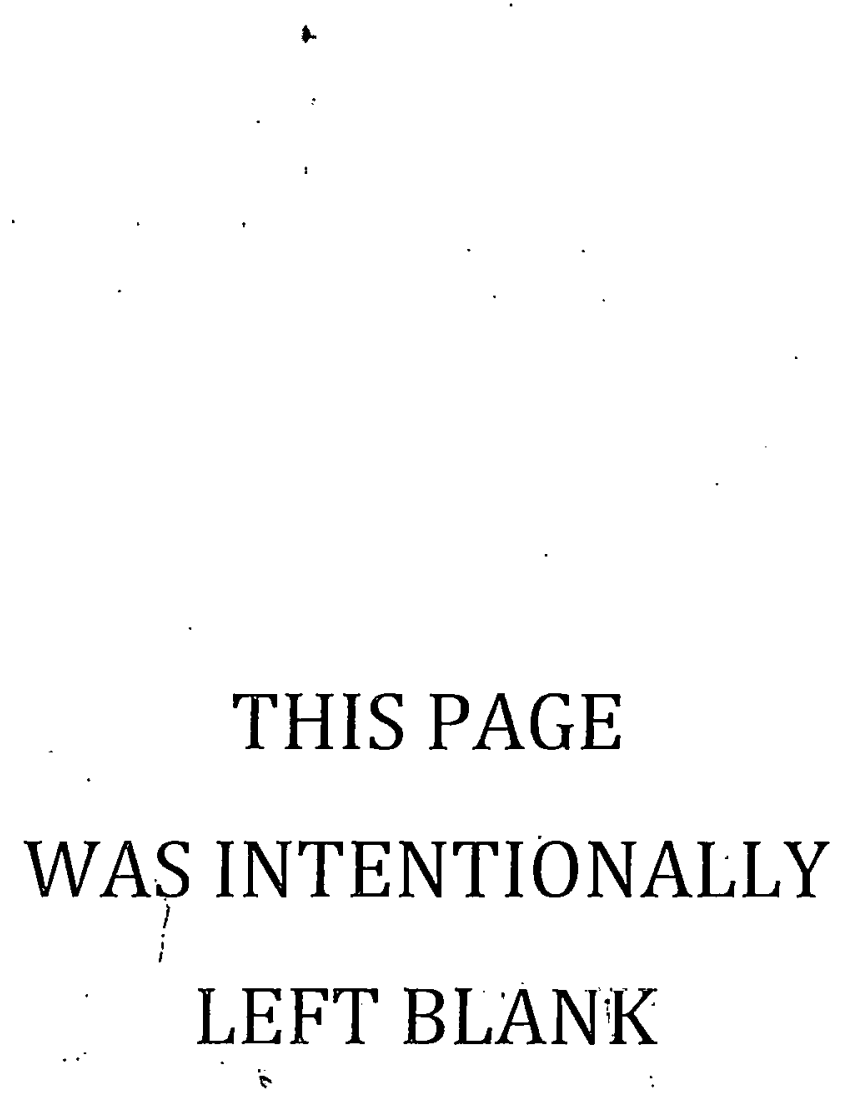

\section{WAS INTENTIONALLY LEFT BLANK}




\section{ESTIMATING LONG-TERM MEAN WINDS FROM SHORT-TERM WIND DATA}

W. R. Barchet and W. E. Davis

\section{SUMMARY}

The estimation of long-term mean winds from short-term data is especially important in the area of wind energy. It is desirable to obtain reliable estimates of the long-term mean wind speed from as short a period of on-site measurements as possible. This study examined seven different methods of estimating the long-term average wind speed and compared the performance of these techniques. Three linear, three weather pattern, and one eigenvector methods were compared for measurement periods ranging from 3 months to 36 months. Average errors, both relative and absolute, and the rms errors in the techniques were determined. The best technique for less than 12 months of measurement was the eigenvector method using weekly mean wind speeds. However this method was only slightly better than the linear adjusted method. When 12 or more months of data were used, the difference in errors between techniques was found to be slight. 


\section{CONTENTS}

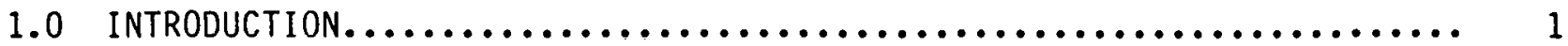

2.0 EXTRAPOLATION TECHNIQUES.................................. 3

2.1 LINEAR............................................. 3

2.2 WEATHER PATTERN TYPING............................... 5

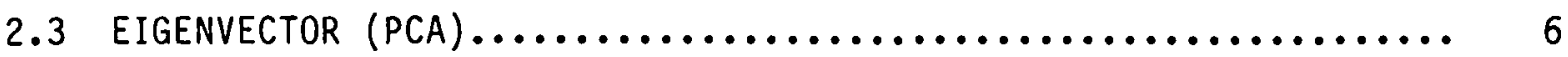

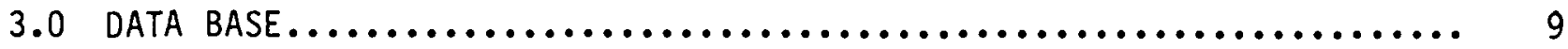

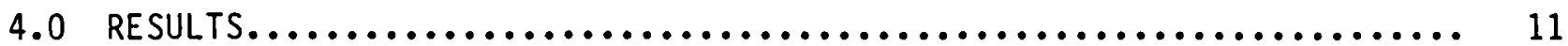

4.1 MEASURES OF TECHNique PERfORMANCE $\ldots \ldots \ldots \ldots \ldots \ldots \ldots \ldots \ldots, 11$

4.2 TECHNIqUe PERFORMANCE................................ 13

5.0 SUMMARY AND CONCLUSIONS................................. 19

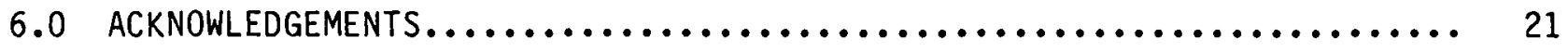

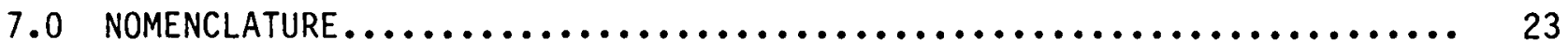

8.0 REFERENCES............................................. 25 


\section{FIGURES}

1 Stations Used in the Evaluation of Extrapolation Techniques.........

\section{TABLES}

1 Great Plains Stations Used to Evaluate Short Record

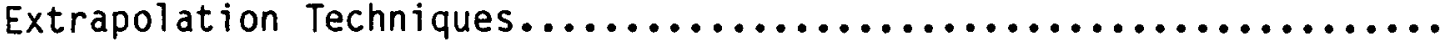

2 Number of Estimates of the Long-Term Mean for Simulated Observation Perinds,....................................11

3 Station Pairs Used to Test the Linear and WPT Techniques that Require a Reference Station.

4 Performance of Extrapolation for the Set of Great

Plains Stations........................................ 14

5 Mean Average Root-Mean-Square Error of Extrapolation Techniques Applied to Two Great Plains Sites......................... 18

6 Ranking of Extrapolation Technique Performance Based on Lowest R.M.S. Error. 


\subsection{INTRODUCTION}

The long-term mean wind speed is an important measure of the quality of a potential site for use in wind energy conversion. In many cases candidate sites; that is, sites which are candidates for the deployment of wind turbines, that appear promising do not have a long period of meteorological record. Thus it is necessary to develop techniques which will indicate how long a period of measurement will be needed to accurately estimate the long-term mean wind speed. The purpose of this study is to demonstrate the capabilities of various techniques to estimate the long-term average wind speed from a short period of record. Furthermore, an estimation of the uncertainty associated with each technique is determined. The result of this study should provide both a technique for using a short period of measurement to estimate the long-term mean and the expected error in using the technique. Ramsdell et al. (1980) used existing long periods of measurement of wind speed at Hanford, Washington, and other sites throughout the United States to establish the period of measurement that should be used to estimate the long-term average. This analysis was not in itself a method of estimating the long-term average wind speed but only an indicator of how long a period of measurement was necessary until the measured mean wind speed approached the long-term average.

In this study seven techniques for extrapolating a short period of wind speed measurement to represent the long-term mean speed are presented. Linear methods that make use of the observed short period mean speed in a linear fashion and scale this speed to represent the long-term mean (Justus et al. 1978, Hiester and Pennel1 1981) are tested. Linear techniques require the least amount of computational power and information about other measurement locations.

Three methods based on the weather pattern type (WPT) climatology at a site (Barchet 1982) were tested. In these methods the long-term climatology of the occurrence of various weather patterns is available independentily of the period of observation. But the mean speed associated with each weather pattern 
is determined at the candidate site for the measurement period. A linear combination of the observed speed for each WPT weighted by the frequency of occurrence gives the long-term mean. These methods require skillful analysis of the meteorology during the period of measurement to identify the weather pattern types.

A recent paper by Barros and Ser'o (1981) demonstrated the use of principal component analysis ( $P C A)$ to estimate the annual average at a station where only a short period of record was available. Barros' technique is extended here to obtain the long-term mean speed. PCA has been widely used in meteorology in rer.ent years. (a) Barnett (1977) esLimlated a two-component wind field pattern in the Pacific trade winds and in the San Francisrn bay area. Bhumralkar et al. (1978) used PCA along with modeling wind flow over local terrain in a wind turbine siting study. The weights computed in this technique were for the stations rather than for each individual wind measurement during the period of concurrent measurement as in Barros' application. PCA techniques require a substantial amount of computation power as well as wind data from sites other than the candidate site.

(a) Smyth, V. G. 1982. A Wind Energy Resource Survey of New Zealand. PhD thesis presented at the University of Canterbury in New Zealand. 


\subsection{EXTRAPOLATION TECHNIQUES}

\subsection{LINEAR}

Linear approaches to estimating the long-term mean from a short period of record are the most straight forward of the approaches tested in this study. The linear approaches require minimal computation. The most widely used linear technique is to assume the short period of measurement represents the long-term mean:

$$
V L S=1 /(P-L) \sum_{i=1}^{P} 0 S_{i}
$$

where VLS is the estimated long-term mean wind speed at the candidate site, L and $P$ represent start and end of the period of observations at the candidate site, and $0 S_{j}$ is the series of observations of wind speed at the site. This technique for extrapolating a short series of observations to the long-term mean will be referred to in subsequent discussions as the "linear" technique.

A variation of the linear technique was described by Justus et al. (1978), and Hiester and Pennell (1981). In this approach, it is assumed that a reference station with a long period of record is available in the vicinity of the candidate site. The ratio of the mean wind speed observed at the candidate site and at the reference site during a period of concurrent observation is used to scale the reference site long-term mean wind speed to approximate the long-term mean at the candidate site:

$$
V L S=V L R * V S / V S R
$$

where VLR is the long-term mean at the reference site, and VS and VSR are the mean speeds for the short period of concurrent record at the candidate site and reference sites, respectively. In terms of the series of observations made at these sites, these mean speeds are defined as: 


$$
V L R=1 / M \star \sum_{i=1}^{M} O R_{i}
$$

where $M$ is the total number of observations of wind speed, $O R_{j}$, at the reference site,

$$
V S R=1 /(P-L) * \sum_{i=L}^{P} O R_{i}
$$

where $L$.and $P$ mark the start and end of the period of concurrent observations at the reference and candidate site such that $1 \leqslant L<P<=M$, and

$$
V S=1 /(P-L) * \sum_{i=L}^{P} O S_{i} \text {. }
$$

This approach will be referred to as the "adjusted" approach to indicate that the mean speed observed at the candidate site has been adjusted by the mean speeds observed at a reference site.

Corotis (1978, Renné and Corotis 1981) also used information from a nearby long-term reference station. His technique was to determine the long-term mean based on the short-term mean wind speed at the site plus an adjustment to the long-term mean wind at the reference station using the spatial correlation between the short-term measurements at the site to the short-term measurements at the long-term reference station. A variance was developed between the site and the reference station for use as an error estimate on the estimated longterm mean wind. This technique was not included in this study.

In the above discussion, VLS is referred to as the estimate of the longterm mean speed at the candidate site. Generally this is taken to mean the long-term annual mean speed. However, the linear approachs can be used to estimate the seasonal mean speed. In this case, season is taken to be the same time period as the sample period in every calendar year. Application of the 
linear method to estimate the long-term seasonal mean speed, hereafter referred to as the "seasonal" technique, is discussed further in the section on measures of technique performance.

\subsection{WEATHER PATTERN TYPING}

Barchet (1982) recently gave the frequency of occurrence of nine weather pattern types for the Great Plains. One objective of this work was to characterize the wind regime of each weather pattern type (WPT) so that the long-term mean speed could be reconstructed from the mean speed associated with each WPT and the frequency of occurrence of the WPT:

$$
V L S=\sum_{k=1}^{9} f S_{k} * V S_{k}
$$

where $f S_{k}$ is the frequency of occurrence of WPT $k$ at the candidate site and $V S_{k}$ is the mean wind speed for WPT $k$ observed at the candidate site. The short period of record at the candidate site is used to "calibrate" the mean speed asscociated with the weather pattern. The frequency of occurrence is determined from the climatology of WPT occurrence over the Great Plains given by Barchet (1982). This technique will be referred to as the "WPT" method of extrapolation. As in the linear approaches describe above, a reference station can be used to help calibrate the mean speed for a WPT and give the estimate of the long-term mean as:

$$
V L S=\sum_{k=1}^{9} f S_{k} \star V L R_{k} V S_{k} / V S R_{k}
$$

where VLR $R_{k}$ and $V S R_{k}$ are equivalent, respectively, to VLR and VLS as defined above in the "linear adjusted" technique except that the speeds refer to those observed for a particular WPT. This technique for short record extrapolation will be referred to as the "adjusted WPT" technique. 
By restricting the comparison of VLS to the same calendar period in other years, the WPT approach can be made into a "seasonal WPT" technique. Evaluation of this technique is discussed in the section on technique performance.

\subsection{EIGENVECTOR (PCA)}

The eigenvector or principal component analysis (PCA) approach has been applied to the generation of annual time series of wind data by Barros and Ser'o (1981). The application here extends Barros' work to generate time series for periods on the order of eight years. This approach relies on having one $n r$ more reference stations at which a long series of wind speed observations is avaliable. These stations provide the basis for generating a long series of wind speeds from a short period of observation at a candidate site.

A matrix $V$ is formed using as columns the reference sites and the rows as the individual wind measurements at the reference sites. The elements of $V$, $v_{i j}$, give the wind speed for observation $i$ and reference station $j$. The PCA assumes that $V$ can be described by the product of two orthonormal matrices

$$
V=A M
$$

in which $A$ is formed by the eigenvectors of the matrix formed by the product of $V$ and its transpose, VT. The multiplier matrix, $M$, is obtained by a linear algebra solution of this expression.

If the number of reference stations is $N$ and the number of observations in the long time series is $M$ then matrix $V$ is of the order $M \times N$. The product of $V$ and $V T$ is of the order $M \times M$ as is the eigenvector matrix $A$. That is, matrix $A$ contains $M$ eigenvectors. However, the number of eigenvectors with non-zero eigenvalues is usually less than or equal to the number of reference stations, N. In practice, time series can be reconstucted with good fidelity using the eigenvectors associated with the first few largest eigenvalues, $N^{\prime}$, so that the eigenvector matrix, $A^{\prime}$, that needs to be dealt with is of the order $M \times N^{\prime}$.

To generate a long time series of wind speed values from a short series obtained at a candidate site it is necessary that the time series at the candidate site be concurrent with part of the time series at the reference sites. 
The PCA approach assumes the time series at the candidate site, Vs, can be constructed from a subset of eigenvectors associated with the reference sites, $A^{\prime}$ and a multiplier vector Ms:

$$
V s=A^{\prime} M S \text {. }
$$

The elements of $V$ are

$$
v s_{i}=\sum_{n=1}^{N^{\prime}} a^{\prime}{ }_{i n} \mathrm{~ms}_{n}
$$

where $a^{\prime}$ in are the elements to $A^{\prime}$ and $\mathrm{ms}_{n}$ are the elements to Ms. The vector $V s$ is the reconstructed time series of observations at the candidate site. Barros and Ser'o (1981) showed that a time series of reasonable fidelity could be formed from as few as three eigenvectors. However, in this study, five eigenvectors $\left(N^{\prime}=5\right)$ were always used to construct the time series.

The root-mean-square (rms) error in the reconstruction of the time series is

$$
E_{S}=\sum_{i=1}^{P}\left(0 S_{i}-\sum_{n=1}^{N^{\prime}} a^{\prime}{ }_{\text {in }} m s_{n}\right)^{2} .
$$

where $O S_{j}$ are the observed wind speeds at the candidate site. The error is minimized by setting

$$
\frac{\partial E S}{\partial m s_{n}}=0
$$

which creates a set of $N^{\prime}$ equations with $N^{\prime}$ unknowns. Linear algebra methods are used to solve for the vector Ms.

Once Ms is known, the long-term mean for the candidate site is estimated by 


$$
\text { VLS }=1 / M \sum_{i=1}^{M} \sum_{n=1}^{N^{\prime}} a^{\prime}{ }_{\text {in }} \mathrm{ms}_{n} .
$$

This approach to extrapolating a short data record will be referred to as the "PCA" method. 


\subsection{DATA BASE}

Eleven stations on the Great Plains with a period of record at constant anemometer height from eight to ten years long were chosen to test the various extrapolation techniques described above. Figure 1 shows the location of these stations on the Great Plains. The stations are listed in Table 1 along with the period of record, anemometer height, and mean wind speed for the period of record and for the eight year period used in the PCA evaluation. The mean speed was determined from an analysis of data on the TD1440 tapes obtained from the National Climatic Center (NCC 1975) for these stations.

The linear and WPT approaches used daily mean wind speeds computed from the hourly observations. The daily mean values approximate what would be obtained with a wind-run anemometer read at $1 \mathrm{pm}$ local time. The PCA-based technique used weekly (7-day) and monthly (30-day) mean speeds calculated by averaging the appropriate number of daily mean values.

TABLE 1. Great Plains Stations Used to Evaluate Short Record Extrapolation Techniques

\begin{tabular}{|c|c|c|c|c|c|c|c|}
\hline WBAN & Station & State & $\begin{array}{l}\text { Start } \\
\text { Period } \\
\end{array}$ & $\begin{array}{c}\text { End } \\
\text { Period } \\
\end{array}$ & $\begin{array}{c}\text { Anemometer } \\
\text { Height } \\
(\mathrm{ft}) \\
\end{array}$ & \multicolumn{2}{|c|}{$\begin{array}{l}\text { Mean Wind Speed } \\
(111 / 5)\end{array}$} \\
\hline 1. 13967 & Oklahoma City & OK & 550101 & 641231 & 55 & 5.98 & 6.01 \\
\hline 2. 13996 & Topeka & KS & 550101 & 640809 & 72 & 5.50 & 5.43 \\
\hline 3. 14918 & Intern'l Falls & MN & 550101 & 630929 & 23 & 4.34 & 4.37 \\
\hline 4. 14931 & Burlington & IA & 550101 & 641231 & 33 & 4.80 & 4.80 \\
\hline 5. 14940 & Mason City & IA & 550101 & 641231 & 20 & 5.51 & 5.65 \\
\hline 6. 14942 & Omaha & NE & 550101 & 630331 & 74 & 5.26 & 5.26 \\
\hline 7. 23054 & Las Vegas & NM & 550101 & 641231 & 26 & 5.52 & 5.23 \\
\hline 8. 23065 & Goodland & KS & 550101 & 640322 & 31 & 5.66 & 5.57 \\
\hline 9. 24023 & North Platte & NE & 550101 & 640811 & 32 & 5.00 & 4.97 \\
\hline 10. 24028 & Scottsbluff & NE & 550101 & 640801 & 50 & 5.34 & 5.28 \\
\hline 11. 24090 & Rapid City & SD & 550101 & 641231 & 32 & 5.13 & 5.09 \\
\hline
\end{tabular}




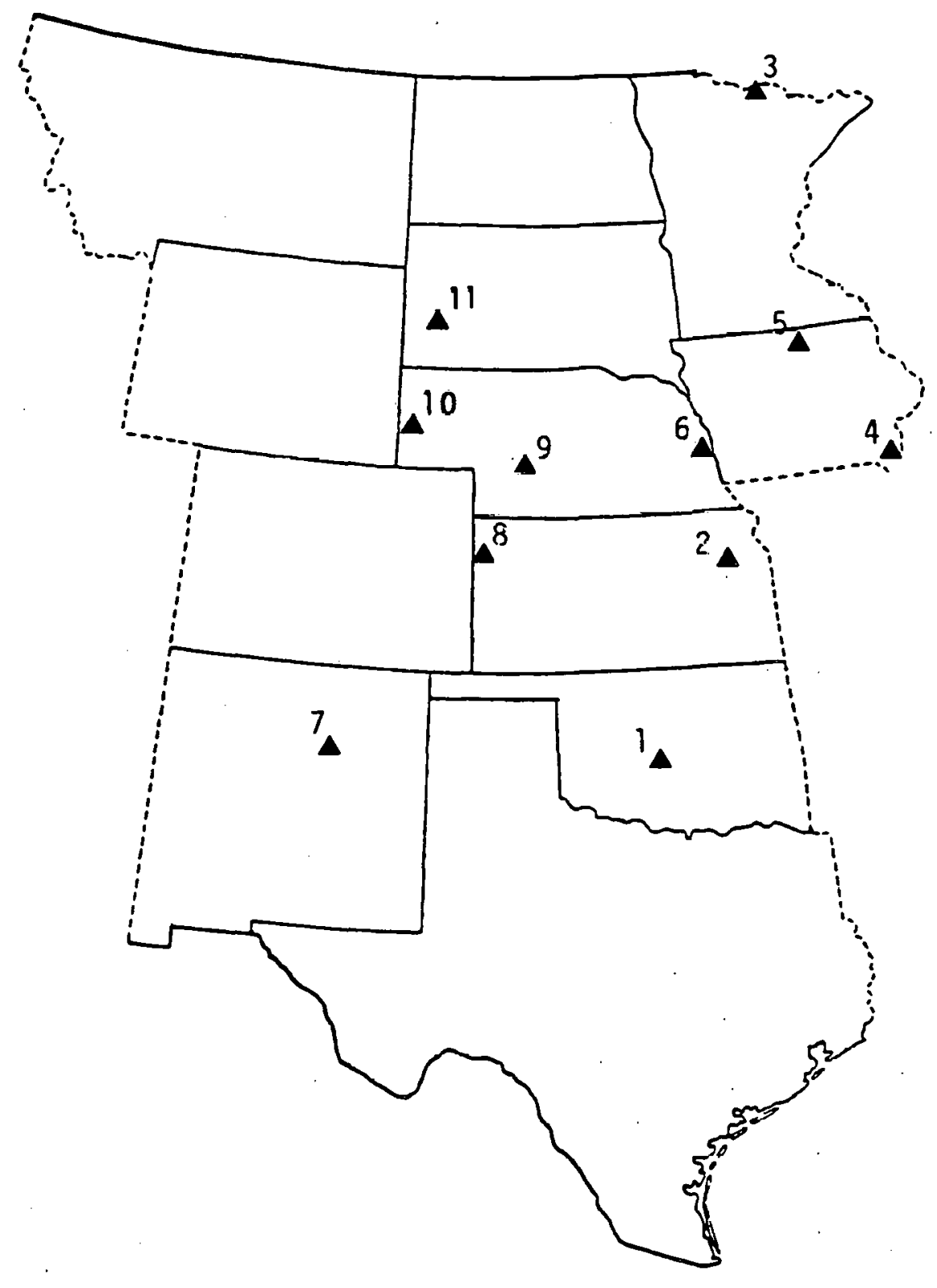

FIGURE 1. Stations Used in the Evaluation of Extrapolation Techniques 


\subsection{RESULTS}

\subsection{MEASURES OF TECHNIQUE PERFORMANCE}

The short record extrapolation techniques described above were tested using simulated short periods of observation of $3,6,12,24$ and 36 months out of the total available period of record. For the linear and WPT techniques, these periods were represented by sequences of $91,182,365,730$, and 1095 days, respectively. For the PCA technique 13, 26, 52, 104 and 156 weeks, respectively, were used to represent the test periods. Seasonal techniques were not tested for sample periods longer than 12 months. The number of estimates of the long-term mean for each sample period is given in Table 2. This is the maximum number of samples of the specified duration that can be obtained from the period of record.

TABLE 2. Number of Estimates of the Long-Term Mean for Simulated Observation Periods

\begin{tabular}{|c|c|c|c|c|}
\hline $\begin{array}{l}\text { Period } \\
\text { Duration } \\
\text { (mo) }\end{array}$ & $\begin{array}{c}\text { Days } \\
\text { in } \\
\text { Period } \\
\end{array}$ & $\begin{array}{c}\text { Samples in } \\
\text { 10-year } \\
\text { Record } \\
\end{array}$ & $\begin{array}{c}\text { Weeks } \\
\text { in } \\
\text { Period } \\
\end{array}$ & $\begin{array}{c}\text { Samples in } \\
\text { 8-year } \\
\text { Record }\end{array}$ \\
\hline 3 & 91 & 3561 & 13 & 403 \\
\hline 6 & 182 & 3470 & 26 & 390 \\
\hline 12 & 365 & 3287 & 52 & 364 \\
\hline 24 & 730 & 2922 & 104 & 312 \\
\hline 36 & 1095 & 2559 & 156 & 260 \\
\hline
\end{tabular}

Three measures of performance are calculated for each sample period and short record extrapolation technique. The average error for all samples for a candidate site is given by

$$
\text { AVEs }=1 / G \sum_{g=1}^{G}\left(V L S_{g}-\text { VTs }\right)
$$

where VTs is the true, observed long-term mean over the period of record at the candidate site as shown in Table $1, G$ is the number of samples in the total 
period of record (approximated in Table 2), and $\mathrm{VLS}_{\mathrm{g}}$ is the estimate of the long-term mean by the extrapolation technique for sample g. The average, absolute error for all samples is given by

$$
A B S s=1 / G \sum_{g=1}^{G}\left(V L S_{g}-V T s\right) \text {. }
$$

And, the root-mean-square error for the samples is given by

$$
\text { RMSS }=\left[1 / G \sum_{g=1}^{G}\left(V L S_{j}-V T s\right)^{2}\right] 1 / 2
$$

for each candidate site.

Performance of the seasonal linear and seasonal WPT techniques is not measured against the long-term annual mean speed. Rather, VTs represents the long-term mean of each season for every calendar year in the period of record. Season here is taken to be the same calendar period as the short term sample. To illustrate, if the 3-month sample went from May 5, 1956 to August 4, 1956, VLS obtained from this period would be compared to VTs determined from all May 5 to August 4 periods within the total record for the candidate site. Application of seasonal techniques is meaningful only for sample periods of 12 months or less.

Mean values of these performance measures for various subsets of the eleven Great Plains stations are used as the final measure of technique performance. The linear, WPT and full PCA techniques made use of the complete set of eleven stations. Out of the eleven stations used in the study two clusters of four stations each were identified for additional study. Scottsbluff, Nebraska, was chosen as the focal point for one cluster; Omaha, Nebraska, for the other. These clusters were used to test adjusted extrapolation techniques and PCA techniques using a small set of reference stations. Table 3 shows the station pairs that were used to arrive at the performance meausures. 
TABLE 3. Station Pairs Used to Test the Linear and WPT Techniques that Require a Reference Station

\begin{tabular}{|c|c|c|c|c|c|c|c|c|c|c|c|c|c|}
\hline & & & & & & fere & ice & Sta & ion & WBAN & & & \\
\hline & & & 1 & 1 & 1 & 1 & 1 & 1 & 2 & 2 & 2 & 2 & 2 \\
\hline & & & 3 & 3 & 4 & 4 & 4 & 4 & 3 & 3 & 4 & 4 & 4 \\
\hline & & & 9 & 9 & 9 & 9 & 9 & 9 & 0 & 0 & 0 & 0 & 0 \\
\hline & Candidate Site & & 6 & 9 & 1 & 3 & 4 & 4 & 5 & 6 & 2 & 2 & 9 \\
\hline WBAN & Station & State & 7 & 6 & 8 & 1 & 0 & 2 & 4 & 5 & 3 & 8 & 0 \\
\hline 13967 & Oklahoma City & OK & & & & & & & & & & & \\
\hline 13996 & Topeka & KS & & & & $x$ & $x$ & $x$ & & & & & \\
\hline 14918 & Intern'l Falls & MN & & & & & & & & & & & \\
\hline 14931 & Burlington & IA & & $x$ & & & $x$ & $x$ & & & & & \\
\hline 14940 & Mason City & IA & & $x$ & & $x$ & & $x$ & & & & & \\
\hline 14942 & Omaha & $\mathrm{NE}$ & & $x a$ & & $x a$ & $x a$ & & & & & & \\
\hline 23054 & Las Vegas & NM & & & & & & & & & & & \\
\hline 23065 & Goodl and & KS & & & & & & & & & $x$ & $x$ & $x$ \\
\hline 24023 & North Platte & NE & & & & & & & & $x$ & & $x$ & $x$ \\
\hline 24028 & Scottsbluff & NE & & & & & & & & $x_{a}$ & $x a$ & & $\mathrm{xa}$ \\
\hline 24090 & Rapid City & SD & & & & & & & & $x$ & $x$ & $\mathrm{x}$ & \\
\hline
\end{tabular}

(a) Reference stations used in PCA technique with 1,2 , or 3 reference stations

Performance of the PCA technique using from one to three reference stations was based on only one or three samples for each of only two stations (see note with Table 3).

\subsection{TECHNIQUE PERFORMANCE}

The performance of the seven extrapolation techniques presented above is shown in Table 4 for each performance measure. In. these tables the performance measures are given as the mean for the set of sites of the average percentage departure from the true long-term mean at each candidate site.

The mean average error (Table $4 a$ ) is always rather small. This indicates that over all samples the errors in estimating the long-term mean nearly 
TABLE 4. Performance of the Extrapolations for the Set of Great Plains Stations

a. Mean Average Error (*) for the Various Techniques

Extrapolation Technique

Linear

Adjusted

Seasonal

WPT

Adjust.ed WPT

Seasonal WPT

PCA-week ly

PCA-monthiy
Months in Sample Period

\begin{tabular}{|c|c|c|c|c|}
\hline 3 & 6 & 12 & 24 & 36 \\
\hline $\begin{array}{r}-0.05 \\
0.42 \\
-0.14\end{array}$ & $\begin{array}{r}-0.24 \\
0.29 \\
-0.09\end{array}$ & $\begin{array}{r}-0.33 \\
0.15 \\
-0.13\end{array}$ & $\begin{array}{c}-0.38 \\
0.01 \\
-.-\end{array}$ & $\begin{array}{l}-0.40 \\
-0.10 \\
-\end{array}$ \\
\hline $\begin{array}{l}-3.79 \\
-2.13 \\
-2.53\end{array}$ & $\begin{array}{l}-1.36 \\
-0.28 \\
-0.81\end{array}$ & $\begin{array}{r}-0.47 \\
0.20 \\
-0.28\end{array}$ & $\begin{array}{c}-0.49 \\
0.04 \\
---\end{array}$ & $\begin{array}{l}-0.47 \\
-0.08 \\
-\end{array}$ \\
\hline $\begin{array}{c}-0.69 \\
-\end{array}$ & $\begin{array}{l}-0.53 \\
-2.05\end{array}$ & $\begin{array}{l}-0.49 \\
-1.20\end{array}$ & $\begin{array}{l}-0.41 \\
-0.97\end{array}$ & $\begin{array}{r}0.30 \\
-0.84\end{array}$ \\
\hline
\end{tabular}

b. Mean Average Absolute Error (*) for the Various Techniques

Extrapolation

Technique

Linear

Adjusted

Seasonal

WPT

Adjusted WPT

Seasonal WPT

PCA-week ly

PCA-monthiy
Months in Sample Period

\begin{tabular}{|c|c|c|c|c|}
\hline 3 & 6 & 12 & 24 & 36 \\
\hline $\begin{array}{l}9.26 \\
6.91 \\
6.10\end{array}$ & $\begin{array}{l}6.83 \\
5.62 \\
5.23\end{array}$ & $\begin{array}{l}4.42 \\
4.20 \\
4.42\end{array}$ & $\begin{array}{l}3.53 \\
3.28 \\
-.--\end{array}$ & $\begin{array}{l}2.46 \\
2.39 \\
---\end{array}$ \\
\hline $\begin{array}{r}10.35 \\
7.75 \\
6.72\end{array}$ & $\begin{array}{l}7.03 \\
5.64 \\
5.30\end{array}$ & $\begin{array}{l}4.46 \\
4.14 \\
4.47\end{array}$ & $\begin{array}{l}3.58 \\
3.17 \\
---\end{array}$ & $\begin{array}{l}2.49 \\
2.27 \\
---\end{array}$ \\
\hline 7.38 & $\begin{array}{l}5.57 \\
9.24\end{array}$ & $\begin{array}{l}4.18 \\
5.25\end{array}$ & $\begin{array}{l}3.21 \\
3.94\end{array}$ & $\begin{array}{l}2.41 \\
2.84\end{array}$ \\
\hline
\end{tabular}

c. Mean Average Root-Mean-Square Error (*) for the Various Techniques

Extrapolation

Technique

Linear

Adjusted

Seasonal
Months in Sample Period

\begin{tabular}{|c|c|c|c|c|}
\hline 3 & 6 & 12 & 24 & 36 \\
\hline $\begin{array}{r}11.40 \\
8.63 \\
7.52\end{array}$ & $\begin{array}{l}8.42 \\
6.99 \\
6.38\end{array}$ & $\begin{array}{l}5.33 \\
5.18 \\
5.31\end{array}$ & $\begin{array}{l}4.17 \\
3.86 \\
-\end{array}$ & $\begin{array}{l}2.80 \\
2.71 \\
-\end{array}$ \\
\hline
\end{tabular}


TABLE 4. (contd)

Extrapolation
Technique

WPT

Adjusted WPT

Seasonal WPT

PCA-week ly

PCA-monthly

\begin{tabular}{|c|c|c|c|c|}
\hline & Mor & Sample & Period & \\
\hline 3 & 6 & 12 & 24 & 36 \\
\hline $\begin{array}{r}12.59 \\
9.62 \\
8.42\end{array}$ & $\begin{array}{l}8.67 \\
7.05 \\
6.56\end{array}$ & $\begin{array}{l}5.41 \\
5.12 \\
5.39\end{array}$ & $\begin{array}{l}4.26 \\
3.79 \\
---\end{array}$ & $\begin{array}{l}2.82 \\
2.61 \\
-\end{array}$ \\
\hline 9.23 & $\begin{array}{r}6.82 \\
12.72\end{array}$ & $\begin{array}{l}4.94 \\
6.50\end{array}$ & $\begin{array}{l}3.64 \\
4.57\end{array}$ & $\begin{array}{l}2.73 \\
3.29\end{array}$ \\
\hline
\end{tabular}

${ }^{*}$ ) expressed as the mean over all sites tested of the average percentage departure from the long-term mean at each candidate site

cancel. However, for the WPT techniques there seems to be a small bias toward an underestimation of the long-term mean by a few percent for the 3-month sample period. PCA techniques also consistently underestimate the long-term mean. This may be due to the use of only five eigenvectors in the construction of the time series.

The mean average absolute error (Table 4b) and mean average root-meansquare(rms) error (Table 4c) are more discriminating measures of technique performance. As expected, both show the same trends with the rms error consistently larger than the absolute error. In the discussion to follow, the rms error will be used to compare the performance of the various extrapolation techniques.

The trend for all extrapolation techniques is for the mean average absolute and mean average rms errors to decrease as the sample period is lengthened. Ramsdell et al. (1980) found the same trend in evaluating several measurement strategies and using essentially the linear method to estimate the long-term mean. The greatest variability in results is found with the 3-month sample period. Techniques gave mean average rms errors ranging from 7.5 to 12.6\%. Whereas, with a 36-month sample the mean average rms error for all techniques converged to about $2.7 \%$ of the long-term mean. Even with a 12-month sample, the rms performance of the techniques is so similar (range from 4.94 to 
$6.50 \%$ ) that the techniques are virtually indistinguishable. The difference in techniques for 3-month and 6-month sample periods offers more opportunity for discussion of results.

Linear techniques performed better than weather pattern based techniques by about one percentage point for the 3-month sample period. This appears to indicate that a 3-month sample is too short to adequately "calibrate" or characterize the mean wind speed associated with a particular WPT. In part this is due to seasonal variations in weather system intensity. However, a comparison of the seasonal techniques st.ill shows the WPT tcchniques perfoullied slightly poorer than their linear. counterparts. But, the affect of seasonal variations in weather system intensity on the long-term estimate is shnwn hy the improvement of the seasonal methods over both linear and WPT methods by about four percentage points and one percentage point over the adjusted techniques. Approaches which use a reference station to adjust the short period observation at the candidate site show about a three percentage point improvement over their unadjusted counterparts.

The PCA technique using 7-day mean wind speeds (PCA weekly) compared closely to the linear adjusted technique at three months and showed slight improvement over other techniques for sample periods of six months or more. With monthly mean wind speeds (PCA monthly) this technique was definitely poorer than the other techniques. This was to be expected considering tht PCA monthly uses about one-fourth the data points of PCA weekly. Still, the difference between PCA monthly and the other techniques is less than two percentage points for sample periods of twelve months or longer.

An important difference between the linear adjusted and PCA techniques is that the adjustment in the linear method is based on the mean speed over the sample period. A single adjustment is made to arrive at VLS. In the PCAweekly approach, every data point (the 7-day mean speeds) is adjusted so that a new time series of adjusted wind speeds is created for the whole 8-year period of record. This new time series is averged over the period of record to obtain VLS.

The PCA technique using one, two, and three reference stations in the immediate vicinity of a candidate site was applied to two sites: Omaha, 
Nebraska (14942) and Scottsbluff, Nebraska (24028). The results for the PCA and other extrapolation techniques applied to these sites are shown in Table 5. In general all techniques performed better for these two stations than the 11-station average. Furthermore, the trends seen in Table $4 \mathrm{c}$ are maintained. However, with a 3-month sample, the PCA technique showed a significantly improved performance over the 10-station result by using from one to three reference stations. Scottsbluff (24028) was very well characterized by a set of three near neighbors. But individually the same three neighbors did poorer. On the other hand, at Omaha, PCA technique performance deteriorated as additional near neighbors were used. An explanation is that reference stations in the vicinity of a candidate site should experience very similar meteorological conditions as at the candidate site and thus serve to better construct the time series at the candidate site. As the network of reference sites expands, distant sites add little additional information to the reconstructed. time series. However, geographical proximity may not be nearly as important as having reference sites with an exposure to the wind that is similar to that at the candidate site.

One result that is quite interesting is the reduction in rms error by using the linear adjusted technique for sample periods of three and six months. Our results for using the longer 12-month period show what Justus et al. (1978) found: little or no improvement occurred when using the linear adjusted technique for a 12-month sample period (see Tables 4 and 5). However, it does appear that the linear adjusted technique is useful in reducing rms errors for sample periods less than 12 months. 
TABLE 5. Mean Average Root-Mean-Square Error of Extrapolation Techniques Applied to Two Great Plains Sites

Extrapolation

Technique

Linear

14942

24028

Adjusted

14942

24028

WPT

14942

24028

Adjusted WPT

$$
14942
$$

24028 -

PCA-10 station

14942

24028

PCA-3 station

14942

24028

PCA-2 station

14942

24028

PCA-1 station

14942

24028
Months in Sample Period

\begin{tabular}{|c|c|c|c|c|}
\hline 3 & 6 & 12 & 24 & 36 \\
\hline $\begin{array}{l}10.31 \\
10.95\end{array}$ & $\begin{array}{l}7.47 \\
7.46\end{array}$ & $\begin{array}{l}5.04 \\
3.42\end{array}$ & $\begin{array}{l}3.53 \\
3.15\end{array}$ & $\begin{array}{l}1.62 \\
2.45\end{array}$ \\
\hline
\end{tabular}

7.68

6.54

5.81

5.27

4.19

3.00

7.93

3.60

2.50

1.49

11.64

7.42

4.89

3.45

1.47

11.86

7.91

4.06

3.75

2.80

8.31

6.27

6.16

5.02

4.01

2.43

2.66

1.37

8.15

5.30

5.21

3.96

3.29

2.63

2.02

1.79

1.23

5.75

5.15

4.02

4.54

3.49

1.43

2.42

2.10

0.88

5.58

6.40

4.69

4.19

3.84

2.26

2.71

1.52

1.69

1.18

5.58

7.02

4.59

3.63

3.78

2.46

2.64

1.35

5.46

2.30 


\subsection{SUMMARY AND CONCLUSIONS}

This study set out to select and test different techniques for estimating long-term average wind speeds at a site with only a short-term record. Techniques selected for testing included linear methods, weather pattern typing methods, and a PCA method.

Table 6 shows the rank of the various extrapolation techniques for each sample period and an overall rank. The PCA-weekly method performed the best overall but was only slightly better than the adjusted linear technique. With a 12-month or longer sample, the difference between techniques is so slight as to make a definitive choice impossible.

Inadequate calibration of the wind speed for a WPT with a short sample period kept the WPT techniques from performing well at the 3- and 6-month sample periods. However, with adequate data $\Leftrightarrow 12$ months) the adjusted WPT was marginally superior to both adjusted linear and PCA techniques.

The requirements for data and the need for computer processing of the data are important factors in choosing an extrapolation technique. PCA methods require the most information and need the greatest amount of computer power. Adjusted techniques, both linear and WPT, need data from at least one other station and only modest computational resources. A definite drawback to the WPT techniques is that they need a fairly sophisticated analysis of the meteorology over the sample period to be useful.

If only three months of data are available at a candidate site and if there are nearby sites with similar wind exposure and long-term record, it is recommended that the PCA-weekly method be applied to estimate the long-term mean. The accuracy of such an estimate should be on the order of $10 \%$ of the long-term mean speed. If computer resources are limited, the two adjusted techniques are recommended. 
TABLE 6. Ranking of Extrapolation Technique Performance Based on Lowest RMS Error

Extrapolation Technique

PCA-weekly

Adjusted linear

Adjusted WPT

Linear

WPT

\begin{tabular}{ccccccc} 
& Rank by & Sample & Period & & $\begin{array}{c}\text { Overall } \\
\text { Rank }\end{array}$ \\
\hline 3 & $\frac{6}{2}$ & $\frac{12}{24}$ & $\frac{36}{3}$ & $\frac{3}{1}$ & 1 \\
1 & 2 & 1 & 1 & 3 & 2 & 2 \\
3 & 5 & 2 & 2 & 1 & 3 \\
4 & 3 & 4 & 4 & 4 & 1 \\
5 & 4 & 5 & 5 & 5 & 5
\end{tabular}




\subsection{ACKNOWLEDGEMENTS}

Contributions to this work by Keith Packard and Neal Hara are gratefully acknowledged by the authors. This work has been funded for the U.S. Department of Energy under Contract DE-AC06-76RLO 1830. 


\subsection{NOMENCLATURE}

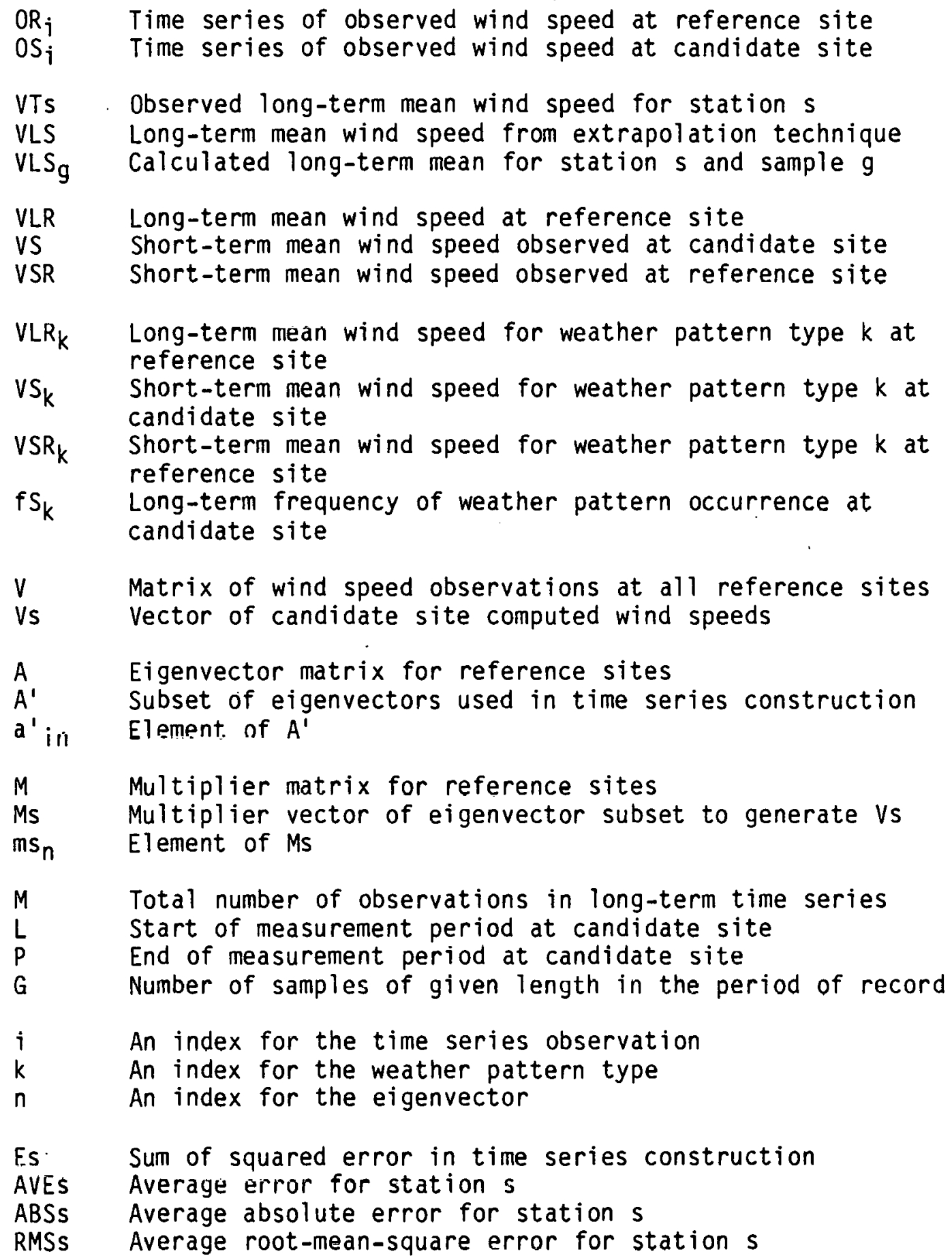




\subsection{REFERENCES}

Barchet, W. R. 1982. A Weather Pattern Climatology of the Great Plains Wind Resource. PNL-4430, Pacific Northwest Laboratory, Richtand, Washington.

Barnett, T. P. 1977. "The Principal Time and Space Scales of the Pacific Trade Wind Fields". J. of the Atmos. Sc., 34: 221-236.

Barros, V. R. and J. A. R. Ser'o. 1981. Measurement Strategies: Use of Short Observation Records for Estimating the Annual Wind Variation. In Proceedings of the International Wind Energy Colloquim on Wind Energy, Brighton, United Kingdom, August 1981.

Bhumralkar, C. M., F. L. Ludwig and R. L. Mancuso. 1978. Estimation of Wind Characteristics at Potential Wind Energy Conversion Sites. PNL-3074, Pacific Northwest Laboratory, Richland, Washington.

Corotis, R. B. 1980. Application of Statistical Techniques to Wind Characteristics at Potential Wind Energy Conversion Sites. DOE/ET/20283-3, Northwestern University, Evanston, Illinois.

Hiester, T. R. and W. T. Penne11. 1981. The Meterological Aspects of Siting Large Wind Turbines. PNL-2521, Pacific Northwest Laboratory, Richland, Washington

Justus, C. G., K. Maui and A. Mikhail. 1978. Interannual and Month-to-Month Variations of Wind Speed. RLO/2439-78/3, Georgia Institute of Technology, Atlanta, Georgia.

National Climatic Center. 1975. TDF-14 Surface Observations. National Oceanographic and Atmospheric Administration, Asheville, North Carolina.

Ramsde11, J. V., S. Houston and H. L. Wegley. 1980. "Measurement Strategies for Estimating Long-Term Average Wind Speeds". Solar Energy, 25: 495-503.

Renne, D. S. and R. B. Corotis. 1981. Assessing the Representativeness of Large Data for Wind Turbine Site Evaluation, In Proceedings of the Large Horizontal-Axis Wind Turbines, pp 173-194, SER I/CP-635-1273, SoTar Energy Research Institute, Golden, Colorado. 


\section{DISTRIBUTION}

No. of

Copies

\section{OFFSITE}

C. I. Aspliden

Battelle Memorial Institute Washington Operations Office 2030 M Street, N.W. Washington, DC 20036

G. P. Tennyson

Department of Energy

Albuquerque Operations Office 4501 Indian School Road N.E.

Albuquerque, NM 87110

J. Cadogan

Wind Energy Technology Division 1000 Independence Avenue

Forrestal Building, Room $5 F 059$ Washington, DC 20585

27 DOE Technical Information Center

R. Nolan Clark

U.S. Department of Agriculture Research Center

Bushland, TX 79012

Clarissa Quinlan

Alaska State Energy Office

338 Denali Street

Anchorage, AK 99501

Tom Gray

American Wind Energy Association

2010 Massachusetts Avenue

Fourth Floor

Washington, DC 20036

Richard Katzenberg

American Wind Energy Association

Natural Power, Inc.

New Boston, $\mathrm{NH} 03070$
No. of

Copies
Fred Whitson

Bendix Field Engineering

Corporation

2582 South Tejon Street

Englewood, CO 80110

John Lowe

Boeing Engineering and Construction

P.0. Box 3707

Mail Stop 9A-65

Seattle, WA 98124

Don McGrew

Boeing Engineering and Construction

P.0. Box 3707, Mail Stop 9A-67

Seattle, WA 98124

Doug Seely

Bonneville Power Administration

P. 0. Box 3621

Purtlarid, OR 97208

S. J. Hightower

Bureau of Reclamation

Denver Federal Center

Building 67 , Code 254

Denver, CO 80225

Joe Hennessy

Wind Energy Program

California Energy Commission

1516 9th Street

Sacramento, CA 95814

Professor Arnold Court

Department of Geography

California State University

Northridge, CA 91130 
Edgar Demeo

Electric Power Research Institute 3412 Hillview Avenue

Palo Alto, CA 94303

5 W. R. Barchet

Environmental Protection Agency

Acid Deposition Staff, RD676

401 M Street S.W.

Washington, DC 20460

Tom Hicster

Flow Wind Corporation

21414-68th Avenue South

Kent, WA 98031

Robert Barton

Advanced Energy Power Division

General Electric Company

Mail Stop 7310

501 Allendale Road, P.0. Box 527

King of Prussia, PA 19406

Art Jackson

Hamilton Standard Division

United Technologies Corporation

Windsor Lock, CN 06096

Anders Daniels, Associate

Professor

Department of Meteorology

University of Hawai i at Manoa

Honolulu, HI 96822

Gary L. Johnson

Electrical Engineering Department

Kansas State University

Manhattan, KS 66506

Abbey Page

Maine Office of Energy Resources

55 Capital

Augusta, ME 04330

J. Konigsberg

Montana Energy Office

Capital Station

Helena, MT 59601
Robert Wasel

Energy Systems Division

National Aeronautics and Space

Administration

600 Independence Avenue, S.W.

Washington, DC 20546

3 Phillip French

NASA Scientific and Technical Information Facility

P.0. Box 8757

Baltimore/Washington International Airport

Baltimore, MD 21240

M. J. Changery

National Oceanic and Atmospheric Administration

National Climatic Center

Federal Building

Asheville, NC 28801

Don Bain

Department of Energy

State of Oregon

Labor and Industries Building

Room 111

Salem, OR 98310

J. E. Wade

Department of Atmospheric Sciences

Oregon State University

Corvallis, OR 97331

3 Ernel L. Luther

Planning Research Corporation

1500 Planning Research Drive

McLean, VA 22102

Terry J. Healy

Rockwell International

Rocky Flats Plant

P. 0. Box 464

Golden, C0 80401 
No. of

Copies

E. Kadlec

Sandia Laboratories

Division 5443, P.0. Box 5800

Albuquerque, NM 87115

Robert Noun

Solar Energy Research Institute

1617 Cole Boulevard

Golden, CO 80401

W. R. Thorn, Manager

Wind Systems Engineering

TERA Corporation

2150 Shattuck Avenue

Berkeley, CA 94704

John Goll

U.S. Minerals Management Service 12203 Sunrise Valley Drive

Mail Stop 640

Reston, VA 22092

Earl L. Davis

U.S. Windpower, Inc.

6421 B. South Front Road

Livermore, CA 94550

Susan Hosch

Washington State Energy Office

$400 \mathrm{E}$. Union Avenue, lst Floor

Olympia, WA 98504

Will Treese

Westinghouse Electric Corporation

Building 8, 4th Floor

875 Greentree Road

Pittsburgh, PA 15220

G. D. Thomann

Wichita State University

P.0. Box 44

Wichita, KS 67208

Farrell Smith Seiler

Wind Energy Report

Box 14 - 104 S. Village Avenue

Rockville Centre, NY 11571
No. of

Copies

Ron Nierenberg

Windfarms, Ltd.

639 Front Street

San Francisco, CA 94111

Dr. V. Barros

28 De Julio 28

9120 Puerto Madryn

Chuiret

R. ARGENTINA

Dr. Ming-I. Lee, Assistant Director

Energy Research Laboratories

Third Floor \#1, Section 1

Fu Shin South Road

Taipei, Taiwan

REPUBLIC OF CHINA

D. Lindley

Taylor Woodrow Construction, Ltd.

Taywood House

345 Ruislip Road

Southal1

Middlesex UBI 2QX

ENGLAND

Dr. Neil Cherry

Lincoln College

Canterbury

NEW ZEALAND

Dr. 011e Ljungstrom

FFA, The Aeronautical Research Institute

Forskningsstationen i Stockholm

Drottning Kristinas Vag 47

S-114 29 Stockholim

SWEDEN

ONSITE

DOE Richland Operations Office

H. E. Ransom 
44 Pacific Northwest Laboratory

J. R. Connell

W. E. Davis (10)

C. E. Elderkin

D. L. Elliott

R. L. George

D. L. Hadley

A. H. Miller

D. C. Powell
D. S. Renné

W. F. Sandusky

H. L. Wegley

L. L. Wendel 1

R. K. Woodruff

Technical Information Library (5)

Publishing Coordination (2)

WCPE Program Office (15) 